\title{
Assimilation of Exogenous Fructose, Aspartate and Some Organic Acids During the Growth of Methylotrophs
}

\author{
By J. COLBY* A ND L. J. ZATMAN \\ Department of Microbiology, University of Reading, Reading $R G$ I $5 A Q$
}

(Received 7 March 1975)

\begin{abstract}
SUMMAR Y
The percentage of bacterial carbon that was derived from exogenous labelled compounds present in the medium during the growth of some methylotrophs on trimethylamine or on non- $\mathrm{C}_{1}$ compounds was determined. Less than $10 \%$ of bacterial carbon was derived from acetate during the growth of the obligate methylotrophs $4 \mathrm{~B} 6$ and $\mathrm{C} 2 \mathrm{AI}$, and of the restricted facultative methylotroph PM6; the other restricted facultative methylotroph W3AI gave a value of $18 \%$. Corresponding values for three typical facultative methylotrophs growing on trimethylamine were $4 \mathrm{I}, 42$ and $52 \%$. Aspartate, fructose, pyruvate and succinate made only a small percentage contribution $(0.4$ to $12 \%)$ to bacterial carbon in $4 \mathrm{~B} 6$, C2AI, W3AI and PM6. Washed suspensions of 4B6, C2AI, W3AI and PM6, all grown on trimethylamine, assimilated labelled acetate only in the presence of trimethylamine and there was a linear relationship between the amount of acetate assimilated and the amount of trimethylamine oxidized. Organisms 4B6, C2AI, W3AI and PM6 assimilated ${ }^{14} \mathrm{C}$ from labelled acetate predominantly into lipid (except PM6), glutamate, arginine, proline and leucine, whereas the typical facultative methylotrophs assimilated ${ }^{14} \mathrm{C}$ from acetate into lipid, nucleic acid and all the protein amino acids. These results are consistent with the presence of a deficient tricarboxylic acid cycle in the obligate methylotrophs and in the restricted facultative methylotrophs.
\end{abstract}

\section{INTRODUCTION}

The isolation and characterization of the obligate methylotrophs bacterium $4 \mathrm{~B} 6$ and bacterium C2AI, and of the restricted facultative methylotrophs Bacillus PM6 and bacterium W3AI, have been described previously (Colby \& Zatman, I973, I975). Enzymological evidence suggests that these methylotrophs have deficient tricarboxylic acid cycles under all growth conditions and that this is in part an explanation of their restricted growth-substrate specificity (Colby \& Zatman, 1972, 1975). These studies have now been extended by investigating the incorporation of some exogenous compounds into whole organisms during the growth of these methylotrophs and also, for comparison, during the growth of the typical facultative methylotrophs bacterium 5BI, Pseudomonas $3 \mathrm{~A} 2$ and Arthrobacter 2B2 (Colby \& Zatman, 1973).

\section{METHODS}

Materials. Standard $\left[\mathrm{I}^{-14} \mathrm{C}\right]$ hexadecane, sodium $\left[\mathrm{I}^{-14} \mathrm{C}\right]$ acetate, sodium $\left[2,3^{-14} \mathrm{C}\right]$ succinic acid, [U-14 C]aspartic acid and $\left[\mathrm{U}^{14} \mathrm{C}\right]$ fructose were obtained from The Radiochemical Centre, Amersham, Buckinghamshire. Unisolve I, xylene (scintillation grade) and $p$ terphenyl (scintillation grade) were obtained from Koch Light. Anderman and Co. Ltd, East Molesey, Surrey, supplied Merck t.l.c. aluminium sheets precoated with Silica gel 60.

* Present address: Department of Biological Sciences, University of Warwick, Coventry CV4 $7 \mathrm{AL}$. 
Autoradiograms were prepared using Kodirex KD54T X-ray film and developed using Kodak Di9 developer and Kodirex fixative (Kodak Ltd, Liverpool).

Growth medium. Organisms were grown in a basal medium consisting of the mineral base E of Owens \& Keddie (1969) supplemented where necessary with filter-sterilized solutions of vitamins. Thus, medium for the growth of bacterium $4 \mathrm{~B} 6$ contained vitamin $\mathrm{B}_{12}(2 \cdot 5 \mu \mathrm{g} / \mathrm{l})$ and media for the growth of bacterium $5 \mathrm{BI}$ contained thiamin hydrochloride $(2 \mathrm{mg} / \mathrm{l})$. Growth substrates, namely trimethylamine hydrochloride, L-alanine, D-glucose, sodium succinate or sodium L-glutamate, were added as filter-sterilized solutions to a final concentration of $20 \mathrm{mM}$. Stock cultures were maintained on slopes of trimethylamine basal medium solidified with $\mathrm{I} \cdot 2 \%$ Oxoid agar No. 2 .

Measurement of growth. Growth was measured spectrophotometrically at $600 \mathrm{~nm}$ on $3 \mathrm{ml}$ samples removed from cultures. Turbidity readings were converted to $\mu \mathrm{g}$ dry wt of organisms $/ \mathrm{ml}$ with a separate calibration curve for each organism. These curves were prepared by drying washed suspensions of exponential-phase organisms of known $E_{600}$ to constant weight.

Incorporation of sodium $\left[\mathrm{I}^{14} \mathrm{C}\right]$ acetate into growing cultures. All cultures were incubated at $30{ }^{\circ} \mathrm{C}$ in shaken $250 \mathrm{ml}$ flasks containing $100 \mathrm{ml}$ medium. Cultures of PM6, $5 \mathrm{BI}$ and 2B2 growing on non- $\mathrm{C}_{1}$ growth substrates were obtained by streaking trimethylamine-grown cultures on to solidified medium containing the appropriate growth substrate. After incubating at $30^{\circ} \mathrm{C}$, isolated colonies were transferred to liquid medium to prepare inocula for the incorporation experiments.

Cultures of the methylotrophs growing on trimethylamine hydrochloride or on non- $\mathrm{C}_{1}$ growth substrates were first adapted to growth in the presence of unlabelled sodium acetate by incubating overnight in medium containing $20 \mathrm{mM}$ growth substrate and 2 mM-sodium acetate. A Io $\mathrm{ml}$ inoculum of this exponential-phase culture was then transferred aseptically to each of three flasks containing $90 \mathrm{ml}$ of basal medium supplemented with growth substrate $(2 \mathrm{mmol})$ and $0.1,0.2$ or $0.5 \mathrm{mmol}$ of filter-sterilized sodium acetate ( $20 \mu \mathrm{Ci}$ sodium $\left.\left[\mathrm{I}^{1}{ }^{14} \mathrm{C}\right] \mathrm{acetate}\right)$. The flasks were incubated and growth followed by taking $E_{600}$ measurements at hourly intervals. At zero time and at hourly intervals, samples (Io ml) of culture were removed and centrifuged, and the pellet was washed twice with $50 \mathrm{~mm}$-sodium phosphate buffer $\mathrm{pH} \mathrm{7.5}$. The washed pellet was then resuspended in I $\mathrm{ml}$ of the same buffer and duplicate $0.2 \mathrm{ml}$ samples plated out on aluminium planchets. Samples were taken over a $6 \mathrm{~h}$ period, which usually corresponded to at least two generation times. Planchets were counted with an MXr23-type Geiger-Müller tube connected to a P7502A-type scaler (Panax Equipment Ltd, Redhill, Surrey). All counts were corrected for the background count and the counting efficiency was approximately $7 \%$.

Incorporation of ${ }^{14} \mathrm{C}$-labelled succinate, aspartate, fructose or pyruvate into growing cultures. These experiments were performed essentially as described above for the incorporation of labelled acetate, except that one amount of labelled compound $(0.5 \mathrm{mmol}$, of specific activity $4 \mu \mathrm{Ci} / \mathrm{mmol}$ ) was used throughout. Cultures were again pre-adapted by incubating them overnight in basal medium supplemented with trimethylamine hydrochloride $(20 \mathrm{~mm})$ and sodium succinate, sodium pyruvate, sodium aspartate or fructose $(2 \mathrm{mM})$. As before, samples (IO $\mathrm{ml}$ ) were taken at hourly intervals, centrifuged, and the pellets washed twice with 50 mM-sodium phosphate buffer $\mathrm{pH}_{7 \cdot 5}$. Each washed pellet was then resuspended in I $\mathrm{ml}$ of glass-distilled water and the suspension transferred to a polythene scintillation vial containing $4 \mathrm{ml}$ of Unisolve $\mathrm{I}$. The centrifuge tube was rinsed with a further $\mathrm{I} \mathrm{ml}$ of water and the washings also transferred to the vial. The vials were shaken vigorously and then left for $24 \mathrm{~h}$ before counting; under these conditions Unisolve I forms 
a clear stable gel. Vials were counted in a Beckman model LS IooC liquid scintillation counter (Beckman RIIC Ltd, Glenrothes, Fife) at $78.4 \%$ efficiency determined by internal standardization with standard $\left[{ }^{14} \mathrm{C}\right]$ hexadecane. All counts were corrected for the background count.

Incorporation of sodium $\left[\mathrm{I}^{-14} \mathrm{C}\right]$ acetate by washed suspensions. Organisms were grown in 21 flasks containing I 1 basal medium supplemented with trimethylamine hydrochloride (20 $\mathrm{mM}$ ) and sodium acetate $(5 \mathrm{~mm})$. The cultures were harvested in mid-exponential phase by centrifuging at $2{ }^{\circ} \mathrm{C}$, washed twice with $50 \mathrm{mM}$-sodium phosphate buffer $\mathrm{pH} 7.5$ and then resuspended in the same buffer to a concentration of $3 \mathrm{mg} \mathrm{dry} \mathrm{wt} / \mathrm{ml}$. To determine the effect of the amount of trimethylamine hydrochloride on the extent of acetate incorporation, Warburg flasks contained (in $3 \mathrm{ml}$ ): washed suspension, $3 \mathrm{mg}$ dry wt; sodium phosphate buffer $\mathrm{pH}_{7.5},{ }_{150} \mu \mathrm{mol}$; sodium $\left[\mathrm{I}{ }^{-14} \mathrm{C}\right]$ acetate $(0.833 \mu \mathrm{Ci} / \mu \mathrm{mol}), 6 \mu \mathrm{mol}$; trimethylamine hydrochloride, o to $30 \mu \mathrm{mol}$. The trimethylamine hydrochloride and the sodium acetate solutions were placed in the side arm. The centre well contained $0.1 \mathrm{ml}$ of $40 \%$ (w/v) KOH. After tipping, oxygen uptake was followed at $30{ }^{\circ} \mathrm{C}$ under air. When no further uptake occurred in any flask, the contents of all the flasks were transferred to tubes and centrifuged at $3000 \mathrm{~g}$ for $15 \mathrm{~min}$. The pellets were washed twice with $50 \mathrm{mM}$-sodium phosphate buffer $\mathrm{pH} 7.5$ and then resuspended in $\mathrm{I} \mathrm{ml}$ of the same buffer. Duplicate samples $(0.2 \mathrm{ml})$ of the washed suspensions were plated out on aluminium planchets and counted with a Geiger-Müller tube as described above.

Fractionation of organisms labelled with sodium $\left[\mathrm{I}^{-14} \mathrm{C}\right]$ acetate. Flasks containing $90 \mathrm{ml}$ basal medium supplemented with $2 \mathrm{mmol}$ trimethylamine hydrochloride and $0.5 \mathrm{mmol}$ sodium acetate $\left(20 \mu \mathrm{Ci}\left[{ }^{14} \mathrm{C}\right]\right.$ acetate) were inoculated with $10 \mathrm{ml}$ of an exponential-phase culture which had been pre-adapted to growth in the presence of sodium acetate as described above. The flasks were incubated shaken at $30^{\circ} \mathrm{C}$ and growth allowed to proceed for two generation times. The cultures were then harvested at $2{ }^{\circ} \mathrm{C}$ by centrifuging and the pellets washed twice with $50 \mathrm{mM}$-sodium phosphate buffer $\mathrm{pH} 7 \cdot 5$. The washed pellets were fractionated according to the procedure of Roberts et al. (1955) and duplicate samples $(0.2 \mathrm{ml})$ of each fraction were plated out on aluminium planchets and counted with a Geiger-Müller tube. The protein residue fraction was hydrolysed for $17 \mathrm{~h}$ under vacuum at $110^{\circ} \mathrm{C}$ with $5 \mathrm{ml}$ of constant boiling hydrochloric acid. The hydrolysate was dried under vacuum at $37^{\circ} \mathrm{C}$ and then resuspended in $5 \mathrm{ml}$ of glass-distilled water before sampling for Geiger-Müller counting. The remainder of the protein hydrolysate was again dried under vacuum and finally resuspended in I $\mathrm{ml}$ glass-distilled water for chromatography.

Resolution of labelled amino acids. Labelled amino acids in the hydrolysed protein were resolved by two-dimensional chromatography on $20 \times 20 \mathrm{~cm}$ aluminium sheets precoated with a $0.25 \mathrm{~mm}$ layer of silica gel. Samples (I to $2 \mu \mathrm{l}$ ) containing about 5000 d.p.m. were applied to the chromatograms and the latter developed with chloroform-methanol-50\% (v/v) aqueous ammonia solution (sp. gr. 0.88) $(2: 2: \mathrm{I}$, by vol.) in the first direction and then with phenol-water $(75: 25, \mathrm{w} / \mathrm{v})$ in the second direction. The position of the radioactive spots was determined by autoradiography. The radioactive areas on the chromatograms were cut out and dropped into polyethylene scintillation vials containing $6 \mathrm{ml}$ of $0.4 \%$ $(\mathrm{w} / \mathrm{v}) p$-terphenyl in xylene. The silica gel layer was scraped off and the aluminium backing removed and discarded. Vials were counted in the liquid scintillation counter at an efficiency of $90 \%$. Approximately $70 \%$ of the d.p.m. applied to the chromatograms were recovered in this way. 


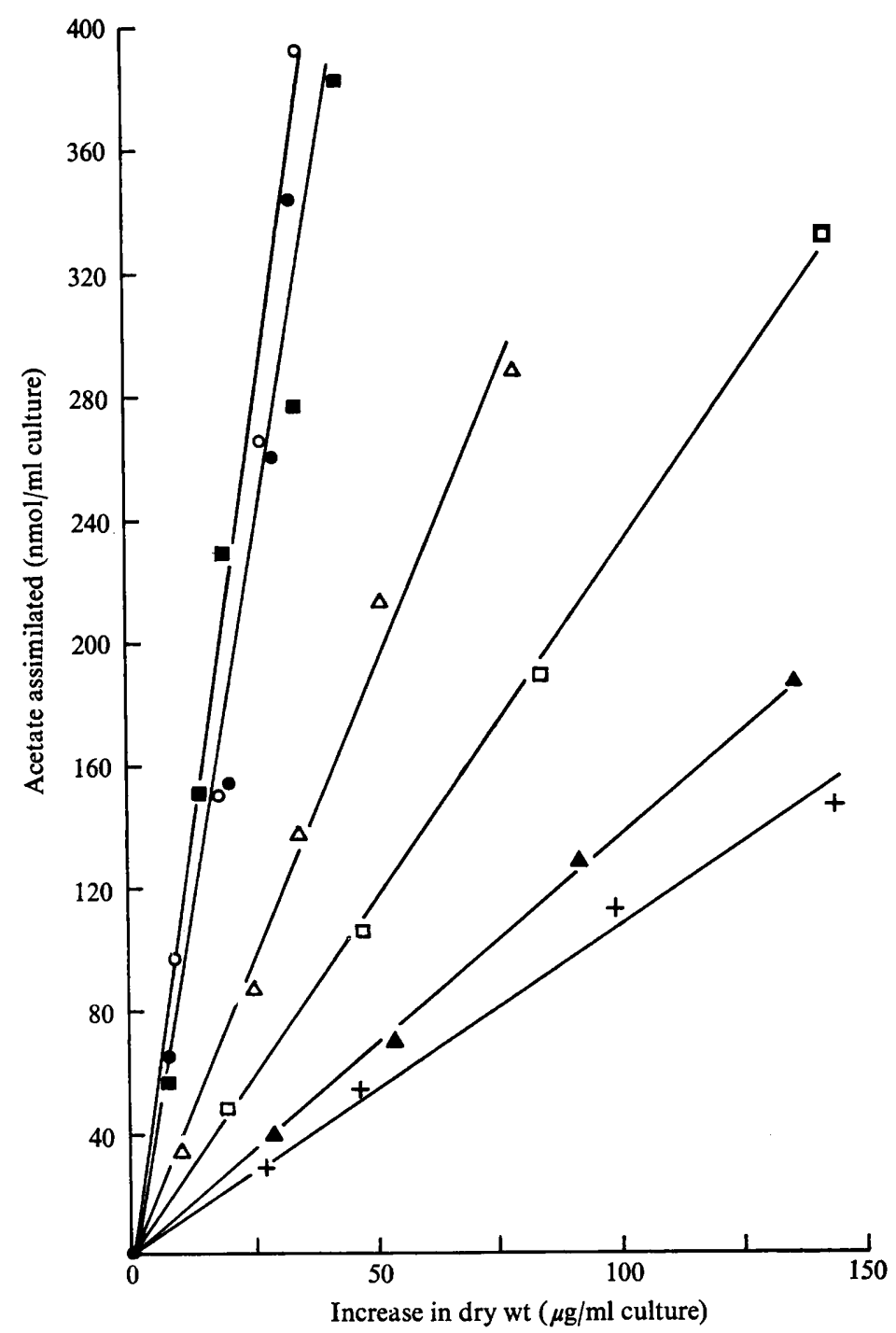

Fig. I. Differential rates of assimilation of acetate into organisms during growth on trimethylamine hydrochloride. To flasks containing $90 \mathrm{ml}$ of basal medium were added $2 \mathrm{mmol}$ of filtersterilized trimethylamine hydrochloride, $0.5 \mathrm{mmol}$ of filter-sterilized sodium acetate $(20 \mu \mathrm{Ci}$ sodium $\left[\mathrm{I}^{14} \mathrm{C}\right]$ acetate) and $\mathrm{IO} \mathrm{ml}$ of exponential-phase organisms. The flasks were incubated at $30^{\circ} \mathrm{C}$ and growth followed by taking $E_{600}$ measurements. Samples (10 ml) were removed at hourly intervals and the bacteria harvested, washed and plated out for counting with a Geiger-Müller tube. $O, 3 \mathrm{~A} 2 ; \square, 2 \mathrm{~B} 2 ; \bullet, 5 \mathrm{BI} ; \triangle$, W3AI; $\square$, PM6; $\triangle$, C2AI; +, 4B6.

\section{RESULTS AND DISCUSSION}

Incorporation of sodium acetate into methylotrophs growing on trimethylamine hydrochloride

The amounts of sodium acetate incorporated into cultures growing in media containing $20 \mathrm{mM}$-trimethylamine hydrochloride and $\mathrm{I}, 2$ or $5 \mathrm{mM}$-sodium $\left[\mathrm{I}^{14} \mathrm{C}\right]$ acetate were measured and plotted as functions of the increase in bacterial density of the cultures. The 


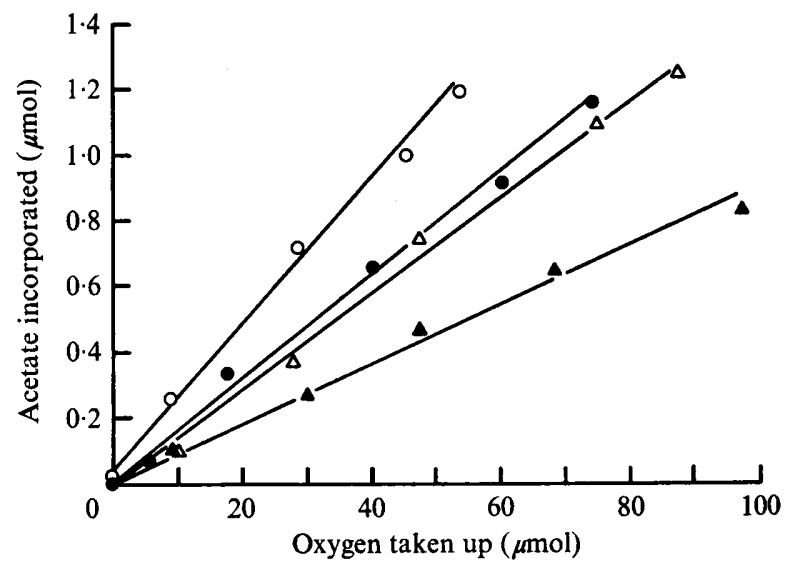

Fig. 2. Acetate incorporation by washed suspensions of 4B6, C2AI, W3AI and PM6 as a function of the amount of trimethylamine oxidized. Warburg flasks contained (in $3 \mathrm{ml}$ ): washed suspension, $3 \mathrm{mg}$ dry wt; sodium phosphate buffer $\mathrm{pH}_{7} \cdot 5,150 \mu \mathrm{mol}$; sodium $\left[\mathrm{I}^{-14} \mathrm{C}\right]$ acetate $(0.833 \mu \mathrm{Ci} / \mu \mathrm{mol})$, $6 \mu \mathrm{mol}$; trimethylamine hydrochloride, 0 to $30 \mu \mathrm{mol}$. Centre wells contained $0.1 \mathrm{ml}$ of $40 \%(\mathrm{w} / \mathrm{v})$ $\mathrm{KOH}$. When no further oxygen uptake occurred, the organisms from each flask were harvested by centrifuging, washed and plated out for counting with a Geiger-Müller tube. O, W3AI; 9 , PM6; $\triangle, 4 \mathrm{~B} 6 ; \triangle, \mathrm{C} 2 \mathrm{AI}$.

Table I. Percentage contribution of exogenous acetate, aspartate, fructose, pyruvate and succinate to new bacterial carbon during growth of the methylotrophs

The procedure was as described in Methods. The values in the Table are mg of labelled compound carbon assimilated/100 mg new bacterial carbon synthesized, and were calculated from the slopes of the graphs (Fig. I).

\begin{tabular}{|c|c|c|c|c|c|c|c|c|}
\hline \multirow[b]{3}{*}{ Labelled compound } & \multicolumn{8}{|c|}{ Methylotroph } \\
\hline & \multicolumn{2}{|c|}{ Obligate } & \multicolumn{3}{|c|}{ Restricted facultative } & \multicolumn{3}{|c|}{ Typical facultative } \\
\hline & $4 \mathrm{~B} 6$ & C2AI & W3AI & PM6 & PM6* & $5 \mathrm{BI}$ & 2B2 & 3A2 \\
\hline Sodium acetate & 5 & 7 & 18 & 9 & 4 & 4I & 42 & 52 \\
\hline Sodium aspartate & I & 2 & 2 & I & I & 12 & 78 & ND \\
\hline Fructose & I & I & 3 & $\mathbf{I}$ & 3 & 68 & 83 & ND \\
\hline Sodium pyruvate & 7 & 9 & 12 & 5 & 8 & 70 & 38 & ND \\
\hline Sodium succinate & 2 & I & 3 & 3 & 5 & IOI & 103 & ND \\
\hline
\end{tabular}

results for cultures containing $5 \mathrm{~mm}$-sodium acetate are shown in Fig. I. The slopes (differential rates of incorporation, in $\mathrm{mmol}$ acetate assimilated/g dry wt increase) were used to calculate the percentage of new bacterial carbon arising from acetate, assuming that carbon accounts for $50 \%$ of the dry weight (Table I). For each organism, the differential rates of incorporation measured with $\mathrm{I}, 2$ or $5 \mathrm{mM}$-sodium acetate in the growth medium were very similar, suggesting that the contribution of acetate to new bacterial carbon is independent of the acetate concentration. In the two obligate methylotrophs $4 \mathrm{~B} 6$ and $\mathrm{C} 2 \mathrm{AI}$, and the restricted facultative methylotroph PM6, less than I0 \% of new bacterial carbon was derived from acetate, whereas in the typical facultative methylotrophs $5 \mathrm{BI}, 3 \mathrm{A2}$ and $2 \mathrm{~B} 2$, acetate contributed 40 to $52 \%$ of the new bacterial carbon. The other restricted facultative methylotroph, W3AI, had an intermediate value of $18 \%$. 
Incorporation of sodium acetate into methylotrophs growing on non- $C_{1}$ compounds

The proportion of new bacterial carbon arising from exogenous sodium acetate was calculated from differential rates of incorporation of sodium $\left[\mathrm{I}^{14} \mathrm{C}\right]$ acetate as described above. The restricted facultative methylotroph PM6 derived only 3 to $8 \%$ of its new carbon from acetate during growth in media containing $5 \mathrm{~mm}$-sodium acetate and alanine, citrate or glucose. Equivalent values for the typical facultative methylotrophs were $44 \%$ for $5 \mathrm{BI}$ growing on glutamate, $27 \%$ for $3 \mathrm{~A} 2$ growing on succinate, and $24 \%$ and $13 \%$ for $2 \mathrm{~B} 2$ growing on alanine and glucose respectively.

\section{Incorporation of ${ }^{14} \mathrm{C}$-labelled sodium succinate, sodium pyruvate, fructose and} sodium aspartate into methylotrophs growing on trimethylamine hydrochloride

Data for the percentage contribution of succinate, pyruvate, aspartate and fructose to new bacterial carbon during the growth of the methylotrophs in media containing trimethylamine hydrochloride (20 $\mathrm{mM})$ and the appropriate labelled compound (5 $\mathrm{mM})$, calculated from differential rates of incorporation as described above, are given in Table $\mathrm{I}$. Similar data are also given in Table I for PM6 growing on alanine (20 mM). The obligate methylotrophs $4 \mathrm{~B} 6$ and $\mathrm{C} 2 \mathrm{Ar}$, and the restricted facultative methylotrophs PM6 and W3AI, assimilated these labelled compounds to a very limited extent $(0.4$ to $12 \%$ of new bacterial carbon), pyruvate being the most extensively incorporated into all the organisms. In contrast, a large proportion ( 38 to $103 \%$ ) of the new bacterial carbon synthesized during the growth of the typical facultative methylotroph $2 \mathrm{~B} 2$ under the same experimental conditions was derived from the exogenous labelled compounds. Similar results to those obtained with 2B2 were obtained with the typical facultative methylotroph 5BI growing on trimethylamine hydrochloride in the presence of labelled succinate, pyruvate or fructose. However, only I2 \% of new bacterial carbon was derived from labelled aspartate during the growth of $5 \mathrm{BI}$ under similar conditions.

\section{Extent of sodium $\left[\mathrm{I}^{14} \mathrm{C}\right]$ acetate incorporation by washed suspensions of 4B6, C2AI, W3AI and PM6}

Washed suspensions of the methylotrophs were incubated in Warburg manometers with a fixed amount of sodium $\left[\mathrm{I}^{14} \mathrm{C}\right]$ acetate and varying amounts of trimethylamine hydrochloride (o to $30 \mu \mathrm{mol}$ ). No oxygen was taken up in the absence of added trimethylamine hydrochloride and the amount of oxygen uptake was proportional to the amount of trimethylamine present. The amount of acetate incorporated into the organisms is plotted in Fig. 2 as a function of oxygen uptake. In each case, a linear relationship was obtained with Io to $24 \mathrm{nmol}$ of sodium acetate being assimilated $/ \mu \mathrm{mol} \mathrm{O} \mathrm{O}_{2}$ taken up. A linear relationship between the amount of sodium acetate assimilated and the amount of $C_{1}$ substrate, in this case methanol, oxidized was also observed by Dahl, Mehta \& Hoare (1972) with another obligate methylotroph, organism wI. Similarly, Hoare et al. (1970) showed that incorporation of labelled acetate into some methane-oxidizing bacteria was dependent on the oxidation of methane or methanol.

A major part of the acetate assimilated by $4 \mathrm{~B} 6, \mathrm{C} 2 \mathrm{AI}$, W3AI and WI enters the lipid fractions of the organisms (Table 2; Dahl et al. 1972). Assuming that malonyl-CoA for fatty acid biosynthesis is derived from the carboxylation of acetyl-CoA, the incorporation of acetate into lipid is presumably independent of intermediates derived from the $C_{1}$ substrate. Under these circumstances, the dependence of acetate incorporation on the presence of the $C_{1}$ substrate is presumably due to the inability of the organisms to obtain energy from 
Table 2. Fractionation of methylotrophs labelled with sodium $\left[\mathrm{I}^{-14} \mathrm{C}\right]$ acetate during growth on trimethylamine hydrochloride

The procedure was as described in Methods.

$\quad$ Fraction
Cold $5 \%$ TCA soluble
Ethanol soluble
Ethanol-ether soluble
Hot $5 \%$ TCA soluble
Protein residue
Ethanol/acid/ether soluble

\begin{tabular}{|c|c|c|c|c|c|c|}
\hline \multicolumn{7}{|c|}{${ }^{14} \mathrm{C}$ in compound $(\%)$} \\
\hline \multicolumn{2}{|c|}{ Obligate } & \multicolumn{2}{|c|}{$\begin{array}{l}\text { Restricted } \\
\text { facultative }\end{array}$} & \multicolumn{3}{|c|}{ Typical facultative } \\
\hline $4 \mathrm{~B} 6$ & C2AI & W3AI & PM6 & $5 \mathrm{BI}$ & $2 \mathrm{~B} 2$ & 3A2 \\
\hline $2 \cdot 9$ & $5 \cdot 0$ & $3 \cdot 1$ & $12 \cdot 8$ & $5 \cdot 2$ & 3.7 & $4 \cdot 9$ \\
\hline $59 \cdot 2$ & $28 \cdot 4$ & $36 \cdot 6$ & $5 \cdot 3$ & $17 \cdot 3$ & 13.4 & $21 \cdot 3$ \\
\hline 3.9 & $14 \cdot 2$ & $8 \cdot 0$ & 0.6 & $2 \cdot I$ & $2 \cdot 4$ & $1 \cdot 4$ \\
\hline $1 \cdot 2$ & $4 \cdot 1$ & $3 \cdot 0$ & I I $\cdot 3$ & $14 \cdot 6$ & $15 \cdot 9$ & I4:I \\
\hline $29 \cdot 9$ & $40 \cdot 7$ & $45 \cdot 8$ & $66 \cdot 9$ & $53 \cdot 7$ & $59 \cdot 9$ & $54 \cdot 3$ \\
\hline $2 \cdot 9$ & $7 \cdot 6$ & $3 \cdot 5$ & $3 \cdot I$ & $7 \cdot I$ & $4 \cdot 7$ & 4.0 \\
\hline
\end{tabular}

TCA, trichloroacetic acid.

the oxidation of acetate, i.e. it is a reflection of their deficient tricarboxylic acid cycles (Colby \& Zatman, 1972, 1975; Dahl et al. 1972). However, PM6 incorporates very little acetate into lipid, the major part being assimilated into the glutamate family of amino acids and into leucine (Table 3). Biosynthesis of these compounds is dependent on intermediates, namely oxaloacetate and pyruvate, which in the absence of isocitrate lyase (Colby \& Zatman, 1975) or of an alternative mechanism for the synthesis of glyoxylate from acetate (Dunstan, Anthony \& Drabble, ${ }_{1972} a, b$ ) must be derived from the $\mathrm{C}_{1}$ substrate. In this case, the dependence of acetate incorporation on the presence of the $C_{1}$ substrate cannot necessarily be correlated with the organism's inability to oxidize acetate or with the presence of a deficient tricarboxylic acid cycle.

\section{Fractionation of methylotrophs labelled with sodium $\left[\mathrm{I}^{14} \mathrm{C}\right]$ acetate during growth on trimethylamine hydrochloride}

The obligate methylotrophs $4 \mathrm{~B} 6$ and C2AI, and the restricted facultative methylotroph W3AI, incorporate sodium acetate largely into the lipid fractions $(42.6$ to $63 . \mathrm{I} \%)$ and into the protein residue fraction $(29 \cdot 9$ to $45 \cdot 8 \%$ ) with only $\mathrm{I} \cdot 2$ to $4 \cdot \mathrm{I} \%$ of the assimilated acetate being incorporated into the nucleic acid fraction (Table 2). In contrast, the three typical facultative methylotrophs $5 \mathrm{BI}, 3 \mathrm{~A} 2$ and $2 \mathrm{~B} 2$ incorporate a greater amount of sodium acetate into the nucleic acid fraction ( 14.1 to $15.9 \%$ ), much less into the lipid fractions ( 15.8 to $22.7 \%$ ) and rather more into the protein residue fraction $(53.7$ to $59.9 \%)$. These results are broadly in agreement with those of Dahl et al. (1972) obtained with the obligate methylotroph wI and with a typical facultative methylotroph, both of which were labelled with sodium $\left[\mathrm{I}^{-14} \mathrm{C}\right]$ acetate during growth on methanol. Similar results to those obtained with 4B6, C2AI, W3AI and WI were also obtained by Eccleston \& Kelly (1973) with the methane-oxidizing bacterium Methylococcus capsulatus, another obligate methylotroph.

The results obtained with the restricted facultative methylotroph Bacillus PM6 differ markedly from those described above (Table 2). This organism incorporates very little carbon from labelled acetate into the lipid fraction ( 6 to $13 \%$ ), presumably because Bacillus species have very little lipid material in their wall (Salton, I964), and the values for the other fractions are correspondingly higher. Nevertheless, the results do resemble those obtained 
Table 3. Distribution of ${ }^{14} \mathrm{C}$ among the amino acids of the hydrolysed protein residue

The procedure was as described in Methods.

\begin{tabular}{|c|c|c|c|c|c|c|}
\hline \multirow[b]{3}{*}{ Compound } & \multicolumn{6}{|c|}{${ }^{14} \mathrm{C}$ in compound $(\%)$} \\
\hline & \multicolumn{2}{|c|}{ Obligate } & \multicolumn{2}{|c|}{$\begin{array}{l}\text { Restricted } \\
\text { facultative }\end{array}$} & \multicolumn{2}{|c|}{ Typical facultative } \\
\hline & $4 \mathrm{~B} 6$ & C2AI & W3AI & PM6 & $5 \mathrm{BI}$ & $2 \mathrm{B2}$ \\
\hline Arginine & $15 \cdot 7$ & $15 \cdot 1$ & $15 \cdot 4$ & I I 9 & $6 \cdot 8$ & $9 \cdot 0$ \\
\hline Glutamate & $45 \cdot 5$ & $40 \cdot 2$ & $41 \cdot 6$ & $40 \cdot 4$ & $15 \cdot 9$ & $17 \cdot 2$ \\
\hline Proline & 20.4 & $I 8 \cdot I$ & $16 \cdot 9$ & I I 5 & $5 \cdot 8$ & $7 \cdot 2$ \\
\hline Leucine/isoleucine/methionine & $18 \cdot 4$ & $2 I \cdot 9$ & $25 \cdot 9$ & 19.9 & $16 \cdot 2$ & I6. I \\
\hline Valine & - & - & - & - & $5 \cdot 6$ & $3 \cdot 0$ \\
\hline Alanine & - & - & 一 & - & $8 \cdot 7$ & $5 \cdot 2$ \\
\hline Glycine/serine & - & - & - & - & $4 \cdot 2$ & $5 \cdot \mathrm{I}$ \\
\hline Phenylalanine & 一 & - & - & 一 & $5 \cdot 9$ & $4 \cdot 3$ \\
\hline Tyrosine & - & - & - & - & $6 \cdot 2$ & $4 \cdot 3$ \\
\hline Aspartate & - & - & - & $6 \cdot 6$ & $7 \cdot 3$ & 13.6 \\
\hline Threonine & - & - & - & $3 \cdot 3$ & $6 \cdot I$ & $4 \cdot 3$ \\
\hline Lysine & - & - & - & $5 \cdot I$ & $10 \cdot 1$ & $10 \cdot 7$ \\
\hline Unknown & - & - & - & $1 \cdot 2$ & I 4 & - \\
\hline
\end{tabular}

-, No radioactivity detected on autoradiogram.

with the obligate methylotrophs and with W3AI in that the percentage of acetate carbon incorporated into the nucleic acid fraction ( $\mathrm{I} \cdot 3 \%$ ) is no greater than that incorporated into the cold trichloroacetic acid pool fraction (12.8\%).

The obligate methylotrophs $4 \mathrm{~B} 6$ and $\mathrm{C} 2 \mathrm{AI}$, and the restricted facultative methylotroph W3AI, incorporated carbon from labelled acetate into the glutamate family of amino acids and into leucine but not into the other protein amino acids (Table 3 ). These results are in accord with the absence of 2-oxoglutarate dehydrogenase from extracts of these organisms (Colby \& Zatman, 1972, 1975). Similar results were obtained with the restricted facultative methylotroph PM6, although some labelling of the aspartate family of amino acids did occur; this is consistent with the low 2-oxoglutarate dehydrogenase activities in extracts of this organism (Colby \& Zatman, 1975). The typical facultative methylotrophs 5BI and 2B2 incorporated radioactivity from labelled acetate into all the protein amino acids.

The restricted incorporation of acetate carbon into glutamate, arginine, proline and leucine has also been observed in the obligate methylotrophs WI (Dahl et al. 1972) and Methylococcus capsulatus (Eccleston \& Kelly, 1973), and this has been correlated with the absence of 2-oxoglutarate dehydrogenase from extracts of these organisms (Dahl et al. 1972; Patel, Hoare \& Taylor, 1969). Another obligate methylotroph, Methanomonas methanooxidans, incorporates acetate carbon into all the protein amino acids (Wadzinski \& Ribbons, 1972), although this cannot necessarily be taken to indicate the presence of a complete tricarboxylic acid cycle in this type II methylobacterium. Methylotrophs using the serine pathway of formaldehyde fixation, such as the type II methylobacteria (Lawrence \& Quayle, 1970) and the typical facultative methylotroph bacterium 5BI (Colby \& Zatman, 1972), presumably incorporate acetate into 2-oxoglutarate, oxaloacetate and phosphoenolpyruvate, and hence into all the amino acid families, independently of a complete tricarboxylic acid cycle. Nevertheless, there is also enzymological evidence indicating the presence of a complete tricarboxylic acid cycle in the type II methylobacteria (Davey, Whittenbury \& Wilkinson, 1972) and in bacterium 5BI (Colby \& Zatman, 1972). For 
organisms such as $2 \mathrm{~B} 2$ which use the hexulose phosphate pathway of formaldehyde assimilation (Cox \& Zatman, 1974) the appearance of carbon from acetate in all the protein amino acids can be taken to indicate a complete tricarboxylic acid cycle. Thus the labelling experiments reported here support the earlier enzymological evidence (Colby \& Zatman, I972, 1975) which suggested that a deficient tricarboxylic acid cycle occurs in the obligate methylotrophs $4 \mathrm{~B} 6$ and $\mathrm{C} 2 \mathrm{AI}$ and in the restricted facultative methylotrophs W3AI and PM6. The labelling experiments also indicate the presence of a complete tricarboxylic acid cycle in the facultative methylotroph 2B2, although the activities of the enzymes in extracts of this organism have not been measured.

This work was supported by a Science Research Council Grant (B/RG/I I407) which is gratefully acknowledged. We thank Mrs M. Forsdyke for her technical assistance.

\section{REFERENCES}

Colby, J. \& ZAtman, L. J. (I972). Hexose phosphate synthase and tricarboxylic acid-cycle enzymes in bacterium 486, an obligate methylotroph. Biochemical Journal x28, 1373-1376.

ColBY, J. \& ZATMAN, L. J. (1973). Trimethylamine metabolism in obligate and facultative methylotrophs. Biochemical Journal 132, IOI-I 12.

Colby, J. \& Zatman, L. J. (1975). Tricarboxylic acid-cycle and related enzymes in restricted facultative

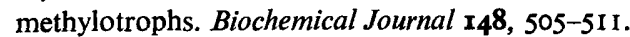

Cox, R. B. \& ZATMAN, L. J. (1974). Hexose phosphate synthase in trimethylamine-grown bacterium 2B2, a facultative methylotroph. Biochemical Journal r41, 605-608.

Dahl, J. S., Mehta, R. J. \& HoARE, D. S. (1972). New obligate methylotroph. Journal of Bacteriology rog, 9I6-92I.

Davey, J. F., Whittenbury, R. \& Wilkinson, J. F. (1972). The distribution in the methylobacteria of some key enzymes concerned with intermediary metabolism. Archiv für Mikrobiologie 87, 359-366.

Dunstan, P. M., Anthony, C. \& Drabble, W. T. (1972a). The involvement of glycollate in the metabolism of ethanol and acetate by Pseudomonas AMI. Biochemical Journal 128, 99-106.

Dunstan, P. M., Anthony, C. \& Drabble, W. T. (1972 $b$ ). The role of glyoxylate, glycollate and acetate in the growth of Pseudomonas AMI on ethanol and on $\mathrm{C}_{1}$ compounds. Biochemical Journal 128, 107-115.

Eccleston, M. \& Kelly, D. P. (1973). Assimilation and toxicity of some exogenous $C_{1}$ compounds, alcohols, sugars and acetate in the methane-oxidizing bacterium Methylococcus capsulatus. Journal of General Microbiology 75, 2 I 1-221.

Hoare, D. S., Hensley, M., Patel, R. \& Taylor, B. F. (1970). Obligate methylotrophs and obligate autotrophs. In Abstracts of the Ioth International Congress for Microbiology, Mexico, p. 42.

LAWRENCE, A. J. \& QUAYLE, J. R. (1970). Alternative carbon assimilation pathways in methane-utilizing bacteria. Journal of General Microbiology 63, 37I-374.

OWENS, J. D. \& KEDDIE, R. M. (1969). The nitrogen nutrition of soil and herbage coryneform bacteria. Journal of Applied Bacteriology 32, 338-347.

Patel, R. N., Hoare, D. S. \& TAylor, B. F. (1969). Biochemical basis for the obligate C-I dependence of Methylococcus capsulatus. Bacteriological Proceedings, 128.

Roberts, R. B., Abelson, P. H., Cowie, D. B., Bolton, E. J. \& Britten, R. J. (1955). Studies of Biosynthesis in Escherichia coli. Publication of the Carnegie Institute 607. Washington: Carnegie Institution.

Salton, M. R. J. (1964). The Bacterial Cell Wall. Amsterdam: Elsevier.

Wadzinski, A. \& RibBons, D. W. (1972). Tricarboxylic acid cycle in the methylotroph Methanomonas methanooxidans. In Abstracts of the 72nd Annual Meeting of the American Society for Microbiology, p. 116 . 